\title{
Implementation Strategy of Secure Electronic Document Management System in National Cyber and Crypto Agency
}

\author{
Chandra Andjar Putra, S.Tr.MP. ${ }^{1}$, Afifah Dalila Yustisia ${ }^{2}$ \\ \{Chandra.andjar@gmail.com ${ }^{1}$, afifahdalila99@gmail.com ${ }^{2}$ \} \\ ${ }^{1}$ Universitas Indonesia, Jakarta, ${ }^{2}$ Padjajaran University, Bandung, Indonesia
}

\begin{abstract}
The support of the use of information and communication technology advances by the government with the implementation of e-government will undoubtedly be one of the determinants of the realization of good governance. One form of e-government implementation in National Cyber and Crypto Agency is the implementation of the Secure Electronic Document Management System (SEDMS). Until 2015, the implementation of SEDMS was considered to be less than optimal due to several obstacles. However, there is an urgency that keeps the Correspondence and Archives section on implementing SEDMS. To be able to support the implementation of SEDMS at National Cyber and Crypto Agency, this research formulated an alteration management strategy. An alteration management strategy is a solution that is expected to be able to resolve existing constraints and can assist the implement SEDMS more optimally. In formulating an alteration management strategy, may be used a SWOT analysis. Critical Success Factor (CSF) that can be used is the Critical Success Factor for Implementing (Electronic Document Management System) EDMS in Government. Then, mapping alteration management strategies using Lewin's Three-Step Change Model.
\end{abstract}

Keywords: E-government, good governance, strategy, alteration.

\section{Introduction}

The use of communication and information technology is growing rapidly. This development has a vast potential for utilization; one of them is to open up opportunities for access, managing, and utilizing information. This will increase the efficiency, effectiveness, transparency, and accountability of government enforcement to support good governance (Presidential Instruction No. 3/2003).

The government supports the use of advances in information and communication technology to conduct good governance. This can be seen from the Presidential Instruction of the Republic of Indonesia No. 3 of 2003 concerning National Policy and Strategy for EGovernment Development, Government Regulation No. 82 of 2012 concerning Electronic System and Transaction, and Regulation of Ministry of State Apparatus Utilization and Bureaucratic Reform No. 6 of 2011 concerning Guidelines for Electronic Service Manuscripts in Government Agencies. E-government must be implemented in all government organizations, including the National Cyber and Crypto Agency (Badan Siber dan Sandi Negara or BSSN). It is applied in order to achieve good governance in government. 
As one part of the organizational structure at National Cyber and Crypto Agency, indeed, the Correspondence and Archives (Correspondence and Archives) needs to support the implementation of E-government. The Correspondence and Archives Section is the part that is on duty with carrying out administrative matters and the coding room at National Cyber and Crypto Agency. In carrying out these duties, the Correspondence and Archives section carries out the functions of the implementation correspondence services, archives, literature, the implementation of code room activities, as well as the administrative services of the Head, Secretary, and Deputy.

As a form to support the implementation of e-government, the Correspondence and Archives Section compiled the concept of electronic administration and organized it in the form of a Secure Electronic Document Management System (SEDMS) application. SEDMS is an electronic administration system that was designed in the SEDMS National Cyber and Crypto Agency masterplan in December 2009 and began to be developed in 2010. Based on information obtained to replace the entire process of correspondence and archives administration from upstream to downstream. In a General Bureau Chief Circular No. 27 of 2012 concerning The Application of Archival Classification Patterns and The Use of Secure Electronic Documents Management System, it is required for every administration in National Cyber and Crypto Agency to use SEDMS. Based on this information, it is known that the implementation of SEDMS is considered to be less than optimal and up to 2015, according to the evaluation report, the activities of the Correspondence and Archives section are still not going well.

The reason is that the implementation of SEDMS is still parallel with manual correspondence, differences in the flow of correspondence services in each work unit, constraints related to letter numbering, and several other technical issues. This causes the user to feel the existence of the application does not simplify the work and feel the time needed to complete the work longer. Other information declares that another problem with the SEDMS implementation process is the mindset of users who feel reluctant to use new technology.

Based on research conducted by Christine in 2014, there is no clear legal and regulatory basis for supporting the management of correspondence system and electronic archives systems. The intended legal and regulatory basis starts from the policies contained in the chief's decree as a legal basis for lower-level regulations such as the Standard Operational Procedure (SOP). This has also become one of the obstacles in implementing SEDMS in the National Cyber and Crypto Agency because, in the absence of binding rules, SEDMS implementation has become less supported in terms of policy outside the general bureau environment.

In addition to the constraints outlined earlier, there is urgency in implementing SEDMS replacing correspondence and archives administration processes. Based on the document review, the information was obtained that in 2013 and 2014 the total number of outgoing and incoming mails in each subsection under the Correspondence and Archives section reached more than three thousand mails, both ordinary and confidential. The maximum number of mails in a subsection reaches more than 14,000 mails. The number of mails caused a high number of human resources and the length of time the letter was worked on [1]. Furthermore, in carrying out their duties, staff in each subsection must also do other things outside of their tasks and functions so that their workload increases.

Another urgency in implementing SEDMS is the process of searching for active or inactive archives. Based on the 2015 Correspondence and Archives section evaluation report, currently searching archives requires a long time, because it is tough to find archives that have been stored long enough but have not yet entered a retention period. With the archive search feature in the SEDMS application, it expected that the archive search process could be done faster. However, this can only be done if SEDMS implemented optimally. 
In 2018 this Correspondence and Archives section will try to implement SEDMS to replace the entire process of correspondence and archives administration. SEDMS is implemented as a solution to meet the needs outlined earlier. However, at the process of replacement, certainly, changes will occur. Problems related to change divided into several dimensions, namely the relationship with human resources, policies, business processes, time, and technology [2]. This, inline with problems related to the implementation of the SEDMS described earlier. Alteration management is a solution needed to deal with changes that occur [3]. In general, alteration management is an approach to plan, formulate, carry out and maintain changes that occur and one form of alteration management is an alteration management strategy [2].

Alteration management strategies can help organizations optimize the implementation of information technology [4]. As for a model of alteration management that recommended is Lewin's Three-Step Change Model [4]. This model used because it is considered useful in implementing information technology in organizations [4]. SEDMS is one form of implementation of information technology in the National Cyber and Crypto Agency to support the administration of correspondence and archives.

Therefore, to support the implementation of SEDMS in order to run optimally, in this research an alteration management strategy was made by using Lewin's Three-Step Change Model to support the SEDMS implementation at National Cyber and Crypto Agency.

\subsection{Problem Formulation.}

The problem formulation in this research is how the alteration strategy that needs to be carried out by the National Cyber and Crypto Agency if wants to implement SEDMS optimally is?

To be able to solve these problems, therefore, the research questions must be answered, i.e:

How is the current condition of the National Cyber and Crypto Agency related to the implementation of SEDMS?

What are the internal and external factors that influence the implementation of SEDMS in the National Cyber and Crypto Agency?

How is an effective alteration management strategy to support the implementation of SEDMS in the National Cyber and Crypto Agency?

\subsection{Research Objectives.}

The objectives of this research are:

To find out the appropriate alteration management methods so that SEDMS can be used optimally.

To find out effective strategies to maximize the implementation of SEDMS and reduce the resistance that might occur if SEDMS applied to the maximum.

\section{Research Methodology}

This chapter discusses the methodology used in research, including research methods, research stages, research variables, populations and samples, data collection techniques, data processing, and analysis techniques. 


\subsection{Research Methods.}

The research method used in this study is a descriptive research method with a qualitative approach. Descriptive method is used to describe the internal and external conditions that support or hamper the process of developing and implementing SEDMS at present, describing the process of formulating strategies, and describing the mapping of strategies into the Lewin's Three-Step Model to the elaboration of change actions to support the development and implementation of SEDMS in the National Cyber and Crypto Agency. As for the qualitative approach in this research is used in the process, collection, presentation, and data analysis techniques related to the alteration management strategy in supporting the implementation of SEDMS in the National Cyber and Crypto Agency.

\subsection{Data Collection Technique.}

Data collection techniques used in this research are observation, review of documents and literature, and are supported by thinking system. The main concept in thinking system is backward thinking [5]. This concept can be used to achieve an expected condition in the organization. The way of thinking the thinking system helps the process to solve complex problems by using a simple method. First, focus on the expected outputs that are encouraged by thinking backward to identify several ways that can be used to achieve the expected outputs.

In this research, the thinking system used as a framework in the process of making an alteration management strategy. The stages that exist in the thinking system are environment, outputs, feedback, inputs, and throughputs. This is a picture of the framework in thinking systems [5].

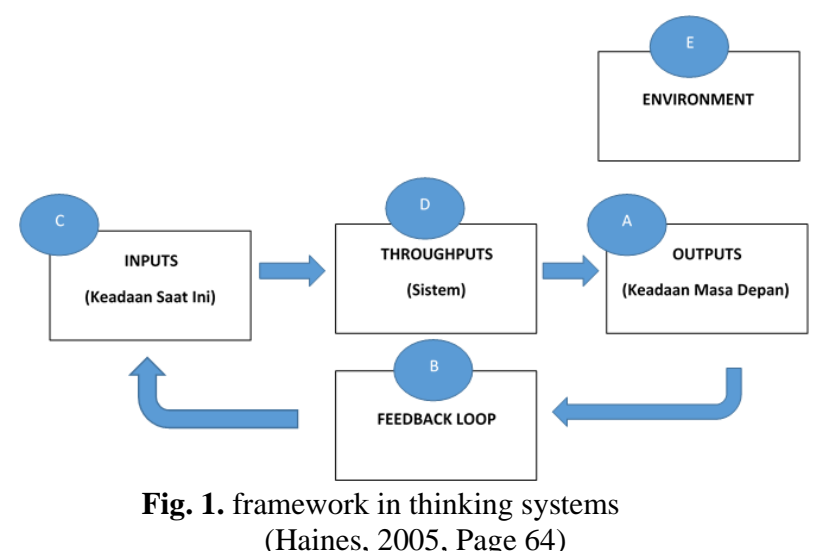

Stages A - Outputs / Positioning Values. In this stage, the organization defined and determines the goals and expected outcomes of the change. The organization must be able to answer the question "where or what kind of position does the organization want?". This stages also means that the organization needs to clearly define the conditions and what ideal purpose that the organization expects from these changes.

Stages B - Feedback Loop. This stage is where the organizations take measurements of their goals. This stage is carried out to determine whether the goals previously made are 
achieved or not. At this stage, the organization must be able to answer the question, "how can the organization know that the organization has achieved its intended goals?". The final results measured at this stage are the final results that have been defining in the previous stage. The organization needs to determine the mechanisms and indicators that can be used to measure the achievement of the final results.

Stage C - Inputs. This stage describes where the organization analyzes the current state of the organization. In this stage, the organization must be able to answer the question, "what is the current condition of the organization?". The organization must define the distance or difference between the organization's current conditions and expected conditions in the future.

Stage D - Throughputs. In this stage, by using thinking systems, organizations begin to make and determine the strategies that need to be done to be able to achieve these final results. Organizations need to define alteration management strategies that integrate all processes, activities, relation, and changes needed to cover the distance or difference between the current organizational conditions (Stage $\mathrm{C}$ ) and expected organizational conditions in the future (Stage A). In this stage, the organization must be able to answer the question "how can the organization achieve the expected results from the organization's current conditions?".

In this research, the thinking system used as a research flow that needs to be followed to get the alteration management strategy.

\subsection{Literature Review.}

The literature review aims to obtain a readings reference and supporting data related to electronic documents and change management. It also carried out excavations of theories, opinions of experts regarding the problem under study. Data collection is done through the process of finding data about things that researched in specific documentation. For example is archives, notes, books, modules and others. The documents used in this research are: SEDMS Masterplan, General Bureau Chief Circular No. 27 of 2012, SEDMS Implementation Progress Report, Evaluation Report on the Activities of the Correspondence and Archives Section of the National Cyber and Crypto Agency, Documents on the Results of the Planning Meeting of the Leaders of the National Cyber and Crypto Agency, and Terms of Reference.

Qualitative data analysis techniques based on Miles and Huberrman are divided into the process of data reduction, the process of presenting data, and the process of drawing conclusions [6]. As for the explanation of the three processes is:

Data Reduction Process. Data reduction is a process of selection, focusing attention on simplification, abstracting, and transformation of archival data arising from written records at the research location. During the research data collection process, the reduction stage is carried out. Further is making a summary, coding, tracing themes, creating partitions, and writing memos. Through data reduction, sharpening activities are carried out, classified, directing, throw away what is not essential, and organize data in such a way that the conclusions can be drawn and diversified.

Data Presentation Process. Data presentation process is a collection of structured information that gives the possibility of drawing conclusions and taking action. Some forms of data presentation include matrices, graphs, networks, charts, etc. The form of data presentation that often used in qualitative research is narrative text. In this stage, triangulation also was done 
either triangulation of data sources or triangulation of data collection. A triangulation of data sources done by providing the same indicators for questions to different informants. Triangulation of data collection is used to ensure that data obtained from data collection techniques are carried out with existing documents.

Drawing Conclusions. At this stage, a search for patterns, explanations, possible configurations, causality, and propositions is carried out. The conclusions also verified during the research.

\subsection{Analysis Result and Recommendation}

This chapter explains the results of the analysis and discussion related to this research. In accordance with the Thinking system research plot, this chapter discusses about the external environment of the National Cyber and Crypto Agency, the current state of the organization, the objectives of SEDMS implementation in the National Cyber and Crypto Agency, and the measurement of the successful implementation of SEDMS in the National Cyber and Crypto Agency.

This chapter also discusses the results of data processing, both primary and secondary. The results of this data processing result in prioritized alteration management strategies that affect the successful implementation of SEDMS in the National Cyber and Crypto Agency. Each section in this chapter adjusts to the stages in the Thinking System research plot.

Determining the Purpose of Implementing SEDMS. This section is stages A in the Thinking System research plot, that is positioning values. In this stage, determined the purpose of the implementation of SEDMS in the National Cyber and Crypto Agency. This section is stages A in the Thinking System research plot, that is positioning values. Determination of the objectives of this implementation generated through a literature study. The following are the objectives of SEDMS implementation based on the 2009 SEDMS National Cyber and Crypto Agency masterplan and other review results (Table I). The purpose of implementing SEDMS is the goal of the strategy created using SWOT analysis.

Table 1. The Purpose of Implementing SEDMS

No. The Purpose of Implementation

1. SEDMS is a product of the National Cyber and Crypto Agency, as a form of application that supports service and facilitates work.

2. SEDMS can be used as an application that has an excellent cryptographic implementation in it. The cryptographic implementation is to guarantee the integrity, availability, authentication, and reliability of the letters and archives that managed. Besides, the implementation of cryptography is expected to be able to guarantee the authentication of a user who manages the letters and archives according to their respective duties and functions.

3. Can build a system that can reduce the role of paper and ultimately will have an impact on the reduced costs that must be incurred for the cost of procuring paper, so that the National Cyber and Crypto Agency can become a less paper office which will eventually become a paperless office. 


\begin{tabular}{ll}
\hline No. & The Purpose of Implementation \\
\hline 4. & SEDMS can integrate and coordinate all scattered and distributed archives and \\
correspondence into an integrated and secure system. The system also expected to \\
be able to cover confidential correspondence in the correspondence and archive \\
section.
\end{tabular}

Critical Success Factor Determination. CSF is everything that when fulfilled will support the achievement of a goal [7]. EDMS is generally described as an application that manages archives or electronic documents through each employee's computer [8]. In measuring success, we used a Critical Success Factor (CSF) for implementing Electronic Document Management Systems (EDMS) in Governments. Bullen and Rockart cited in 1981 (Alshilby et al., 2016) explained that the use of CSF in the implementation of EDMS is beneficial for leaders in making implementation strategies.

The SEDMS application functions as a support for the administration of correspondence and archiving in the National Cyber and Crypto Agency. This is in line with the function of EDMS as an application that manages archives or electronic documents. Therefore Critical Success Factor (CSF) for implementing Electronic Document Management Systems (EDMS) in Governments was used in this research.

Table II CSF relating to the objectives of SEDMS implementation in the National Cyber and Crypto Agency.

Table 2. Critical Success Factor Determination

\begin{tabular}{|c|c|c|c|}
\hline No & Goals & $\begin{array}{c}\text { Critical Success } \\
\text { Factor (CSF) }\end{array}$ & Requirements for CSF Success \\
\hline 1. & $\begin{array}{l}\text { SEDMS is a } \\
\text { product of the } \\
\text { National Cyber and } \\
\text { Crypto Agency, as } \\
\text { a form of } \\
\text { application that is } \\
\text { supportive service } \\
\text { and facilitates } \\
\text { work. }\end{array}$ & $\begin{array}{l}\text { Resource } \\
\text { availability, } \\
\text { Top management } \\
\text { support, } \\
\text { Technological } \\
\text { readiness, Work } \\
\text { atmosphere and } \\
\text { culture. }\end{array}$ & $\begin{array}{l}\text { The availability of resources } \\
\text { could be successful if there are } \\
\text { sufficient financial resources, the } \\
\text { availability of human resources, } \\
\text { sufficient technical resources, } \\
\text { and conditional procurement. } \\
\text { Top management's support could } \\
\text { be successful if there are } \\
\text { leadership and commitment, } \\
\text { encouragement, and leadership }\end{array}$ \\
\hline 2. & $\begin{array}{l}\text { SEDMS can use as } \\
\text { an application that } \\
\text { has an excellent } \\
\text { cryptographic } \\
\text { implementation in } \\
\text { it. The } \\
\text { cryptographic } \\
\text { implementation is } \\
\text { to guarantee the } \\
\text { integrity, } \\
\text { availability, } \\
\text { authentication, and }\end{array}$ & $\begin{array}{l}\text { Training and } \\
\text { involvement, } \\
\text { System related } \\
\text { factors }\end{array}$ & $\begin{array}{l}\text { support. } \\
\text { Technology readiness could be } \\
\text { successful if infrastructure } \\
\text { readiness and developmental } \\
\text { readiness met. } \\
\text { The work atmospehere and } \\
\text { culture could be thriving if the } \\
\text { rules, excellent communication, } \\
\text { alteration management, } \\
\text { cooperation, and problem- } \\
\text { solving as a team have been } \\
\text { fulfilled. }\end{array}$ \\
\hline
\end{tabular}




\begin{tabular}{|c|c|c|c|c|}
\hline No & Goals & \multicolumn{2}{|c|}{$\begin{array}{c}\text { Critical Success } \\
\text { Factor (CSF) }\end{array}$} & Requirements for CSF Success \\
\hline 3. & $\begin{array}{l}\text { reliability of the } \\
\text { mails and archives } \\
\text { that managed. In } \\
\text { addition, the } \\
\text { implementation of } \\
\text { cryptography is } \\
\text { expected to } \\
\text { guarantee the } \\
\text { authentication of } \\
\text { users who manage } \\
\text { the mails and } \\
\text { archives according } \\
\text { to their respective } \\
\text { duties and } \\
\text { functions. } \\
\text { Could build a } \\
\text { system that can } \\
\text { reduce the role of } \\
\text { paper and will } \\
\text { ultimately have an } \\
\text { impact on the } \\
\text { reduced costs } \\
\text { incurred for the cost } \\
\text { of procuring paper, } \\
\text { so that the National } \\
\text { Cyber and Crypto } \\
\text { Agency can } \\
\text { become a less paper } \\
\text { office which will } \\
\text { eventually become } \\
\text { a paperless office. }\end{array}$ & $\begin{array}{l}\text { Technological } \\
\text { readiness, } \\
\text { management } \\
\text { support, } \\
\text { atmospehere } \\
\text { culture. }\end{array}$ & $\begin{array}{r}\text { Top } \\
\text { Work } \\
\text { and }\end{array}$ & $\begin{array}{l}\text { Training and involvement could } \\
\text { be successful if there are } \\
\text { adequate information and } \\
\text { training, training for specific } \\
\text { jobs, good user involvement, } \\
\text { stakeholder involvement, and } \\
\text { participation in decision making.. } \\
\text { System-related factors fulfilled if } \\
\text { SEDMS is useful for work, } \\
\text { SEDMS makes correspondence } \\
\text { effective and efficient, SEDMS } \\
\text { becomes a user-friendly } \\
\text { application, SEDMS becomes a } \\
\text { reliable application, interrogation } \\
\text { of technology in good } \\
\text { organizations and there are } \\
\text { benefits for the organization. }\end{array}$ \\
\hline
\end{tabular}

Based on stage B in the Thinking System, namely measuring goals, is the identification stage to explain the critical determinants of successful SEDMS implementation in the National Cyber and Crypto Agency. At this stage, indicators were also identified that were expected to be a sign of the successful implementation of SEDMS in the National Cyber and Crypto Agency.

Table II explains some of the factors and indicators that need to consider in implementing SEDMS in the National Cyber and Crypto Agency. Each goal has several factors and indicators that intersect with each other. This explains that if one indicator can be met in one goal, it will affect the success of the other goals. The result of this section is to find out the factors that need to consider so that objectives can be achieved. As for achieving these objectives, could by formulating a strategy using a SWOT analysis. 
Analysis of Current Organizational Conditions. By the Thinking System research plot, stage $\mathrm{C}$ is Assessment Strategies. In this stage, the current state of the organization explained. Observation of the current condition of the organization is done by holistically looking at facts on the ground based on CSF. By analyzing the current condition of the organization, it can be seen the strengths and weaknesses of the organization, which later as internal factors that will include in the SWOT analysis. The next SWOT analysis will be used to create alteration management strategies.

Analysis of Current Conditions. Through the document review process, information was obtained that in the development and application of SEDMS, infrastructure had been prepared in stages. Basically, problems related to correspondence and archives in the National Cyber and Crypto Agency will be resolved if SEDMS is implemented optimally because based on the information obtained, all SEDMS features can now be used. Moreover, with the existence of SEDMS, the role of the processing unit can be replaced, so that it will further streamline the existing process.

Concerning the support of Top Management, the leaders did support it well, but in reality, the leaders wanted assistance from the SEDMS helpdesk team or his assistant. This is because the current leaders are not used to electronic correspondence and disposition. For the time being, support is provided in the form of directives and instructions, but the leaders cannot adjust to the use of the application.

The encouragement and motivation of the leaders regarding the implementation of SEDMS are excellent. Based on a joint agreement, the 2018 leadership planning work meeting the leader ordered the administration and finance sections together with the public relations department to develop the SEDMS. Certainly, with the existence of such directives, the process of developing and implementing SEDMS has become more supported.

From echelon 3 and 4 levels, the support provided is to give time for the socialization team to simulate the application. From the evaluation conducted, there is resistance, but the level is just not familiar with electronic applications.

Related to the socialization SEDMS, it has been done repeatedly, namely by conducting Training for administrative, staff and structural sub-division within the main Secretariat. Followed by active participation from users in the form of suggestions to facilitate the use of the application.

Relation to information related to SEDMS from the public relations department has tried to inform the existence of SEDMS. The education and training center also asked the administration and finance sections to make SEDMS a part of secret education and training service. Basically, the existence of SEDMS has been known by all administration, but in reality, it has not been implemented.

Related to specialized training for managers, has already been done. The training was in the form of technical guidance to relevant staff, as well as echelon 3 and 4 officials in the central secretariat environment. The main obstacle in the technical guidance process that carried out door-to-door is the implementation time in conjunction with the activities in the intended section or subsection so that the implementation of technical guidance delayed. Regarding user participation, from the trial evaluation conducted, the organizer of the trial requests input related to the obstacles encountered. The trial participants also gave input related to matters that were technical or non technical. The current shortcomings related to the implementation of SEDMS trials that there are no teams that have been explicitly designating as the managers of SEDMS.

Concerning about decision making, in the series of SEDMS implementation processes always made a report on implementation by the organizing team. The report contains constraints 
and the extent to which SEDMS has been implemented. From the results of the report, the leaders determine the steps for the next process.

Financial resources for the development and implementation of SEDMS are allocating from the APBN. Concerning the availability of human resources, there is no special team to handle the SEDMS implementation process formally, there is no competent human resources or has been instructed to develop SEDMS independently without vendor assistance. Based on reports on the progress of the implementation of SEDMS in 2018, it is necessary to transfer the development of the current vendor to personnel in the National Cyber and Crypto Agency who are accustomed to or competent in programming to reduce dependence on the vendor.

Based on the results of the trial evaluation, the participants presented some technical issues, namely a specific computer for writing letters on the financial chart, having problems with the browser and network so that they could not operate the SEDMS application on the computer. Moreover, another technical support has been provided by the National Cyber and Crypto Agency, for example, in the form of technicians to help deal with problems during trials.

Regarding conditional procurement, as discussed earlier, one of the shortcomings of the SEDMS development process is that the application developing by the vendor. Based on the SEDMS terms of reference, there are several features that vendors fail to fulfill. If there is already an agreement made by the National Cyber and Crypto Agency with a vendor stating that the vendor can fulfill all the demands or requests of the institution, this should not happen. Related to this, it requires a firm responsible for the vendor to meet the demands that are within the terms of reference. So that the SEDMS application is as expected.

Basically, SEDMS functions to electronize correspondence and archives business processes in the National Cyber and Crypto Agency, specifically the Correspondence and Archives section. The benefits of this electronization are the reduced use of paper, the effectiveness, and efficiency of correspondence, reducing courier services. However, in reality, SEDMS is currently only used for letter numbering, and the letter number function still has problems in the form of number redundancy issued.

Regarding the effectiveness and efficiency of correspondence, the SEDMS application features have been using entirely. The server used is Apache, using Oracle database, PHP programming language. The security contained in SEDMS is one-way encryption of password data, account locking for three incorrectly entered passwords and management of user access rights. If examined from the purpose of its implementation, SEDMS will replace the entire process of regular correspondence administration, disposition, and archives. Therefore, there should be encryption features on confidential letters as well as features that guarantee the integrity and authentication of letters, dispositions, and archives. In fact, these features have not been added to the application.

The supporting features of the correspondence and archiving process in the SEDMS application are features for managing incoming and outgoing mail, features for managing information on decisions mail, warrant, and other official mails in accordance with the official script procedures National Cyber and Crypto Agency, archiving information management features, government service script template module, management features of official dispositions and official letters, quest mails government service and archive features, management features of express/instant/ordinary mail, management features of ordinary and confidential letters, and features in the form of executive summary on the initial menu in the form of correspondence and filing reports that are updated periodically. Related to regulations, until now there are no regulations that govern the mandatory use of this SEDMS application. 
Formulation of Alteration Management Strategy. The formulation of an alteration management strategy is the first step in stage D of the Thinking System research plot. The formulation of an alteration management strategy for the implementation of SEDMS begins with identifying internal factors consisting of strength, weakness, and external factors consisting of opportunity, and organization threat.

Identification of internal and external factors of the organization obtained through analysis of the results of observations of the current organizational conditions that have described. The following is a table identifying internal and external factors that are owned by the organization.

Table 3. Internal and External Factors

\begin{tabular}{|c|c|c|}
\hline No & Factors & Classification \\
\hline 1 & $\begin{array}{l}\text { Availability of supporting infrastructure for } \\
\text { SEDMS implementation. }\end{array}$ & External \\
\hline 2 & Technology integration. & External \\
\hline 3 & Leader support for the implementation of SEDMS. & External \\
\hline 4 & $\begin{array}{l}\text { Regulations that support the implementation of } \\
\text { SEDMS. }\end{array}$ & External \\
\hline 5 & Management organizational structure of SEDMS. & External \\
\hline 6 & $\begin{array}{l}\text { Utilization of SEDMS in achieving the } \\
\text { organization's vision and mission. }\end{array}$ & Internal \\
\hline 7 & $\begin{array}{l}\text { User participation in the series of SEDMS } \\
\text { implementation processes. }\end{array}$ & External \\
\hline 8 & Information related to SEDMS. & Internal \\
\hline 9 & $\begin{array}{l}\text { Competence of SEDMS users within the National } \\
\text { Cyber and Crypto Agency. }\end{array}$ & External \\
\hline 10 & $\begin{array}{l}\text { Competence of SEDMS managers within the } \\
\text { National Cyber and Crypto Agency. }\end{array}$ & Internal \\
\hline 11 & $\begin{array}{l}\text { Contribution to the development of SEDMS with } \\
\text { other parties. }\end{array}$ & External \\
\hline 12 & Budget availability. & External \\
\hline 13 & Availability of SEDMS manager human resources. & Internal \\
\hline 14 & SEDMS development internally. & Internal \\
\hline 15 & Effectiveness and efficiency of correspondence. & Internal \\
\hline 16 & $\begin{array}{l}\text { The function of confidentiality of SEDMS in } \\
\text { handling confidential mails. }\end{array}$ & Internal \\
\hline 17 & $\begin{array}{l}\text { The function of SEDMS in ensuring the integrity } \\
\text { and authentication of dispositions and ordinary } \\
\text { mails. }\end{array}$ & Internal \\
\hline 18 & $\begin{array}{l}\text { The function of SEDMS in ensuring the integrity } \\
\text { and authenticity of the archive. }\end{array}$ & Internal \\
\hline 19 & $\begin{array}{l}\text { The long-term effect of implementing SEDMS on } \\
\text { correspondence business processes. }\end{array}$ & External \\
\hline 20 & Convenience of using SEDMS. & Internal \\
\hline 21 & $\begin{array}{l}\text { Planning for the implementation of SEDMS within } \\
\text { the National Cyber and Crypto Agency. }\end{array}$ & Internal \\
\hline 22 & $\begin{array}{l}\text { Implementation of SEDMS in improving employee } \\
\text { performance. }\end{array}$ & Internal \\
\hline
\end{tabular}




\begin{tabular}{cll}
\hline No & Factors & Classification \\
\hline 23 & $\begin{array}{l}\text { The Culture of Electronization in the National } \\
\text { Cyber and Crypto Agency. }\end{array}$ & External \\
24 & $\begin{array}{l}\text { Motivation of users of SEDMS within the National } \\
\text { Cyber and Crypto Agency. }\end{array}$ & External \\
25 & $\begin{array}{l}\text { Organizational readiness for SEDMS applications. } \\
\text { Employee commitment in the process of } \\
\text { implementing SEDMS. }\end{array}$ & $\begin{array}{l}\text { External } \\
\text { Internal }\end{array}$ \\
\hline
\end{tabular}

Source: Analysis Results.

Referring to (Rangkuti, 2002), based on the value of general preferences, internal factors are divided into two, namely strengths and weaknesses. A factor is said to be a strength (S) if the factor preference value is higher than the general preference value. Otherwise, if the factor preference value is smaller than general preference, then the factor is said to be a weakness (W). This also applies to the opportunity factor $(\mathrm{O})$ and threat $(\mathrm{T})$. The general preference values for each factor are derived from the average of each factor's preferences. Based on the tabulations that have been made, the value of general preferences for internal factors is 3,6. So, if an internal factor has a preference value greater than 3.6 it is said to be a strenght factor, and if an internal factor has a preference value less than 3.6, then it is said to be a weakness factor.

Table 4. Strength Factor

\begin{tabular}{clll}
\hline No & Strength Factor & Code \\
\hline 1 & $\begin{array}{l}\text { Utilization of SEDMS in achieving the } \\
\text { organization's vision and mission. }\end{array}$ & S2 \\
2 & $\begin{array}{l}\text { Information related to SEDMS. } \\
\text { Implementation of SEDMS in improving } \\
\text { employee performance. }\end{array}$ & S3 \\
4 & $\begin{array}{l}\text { The function of SEDMS in ensuring the integrity } \\
\text { and authentication of dispositions and ordinary } \\
\text { mails. } \\
\text { The function of SEDMS in ensuring the integrity } \\
\text { and authenticity of the archive. }\end{array}$ & S5 \\
Effectiveness and efficiency of correspondence. & S6 \\
\hline
\end{tabular}

Source: SWOT Tabulation Results.

Table 5. Weakness Factor

\begin{tabular}{lll}
\hline No & Weakness Factor & Code \\
\hline 1 & Convenience of using SEDMS. & $\mathrm{W} 1$ \\
2 & $\begin{array}{l}\text { Employee commitment in the process of } \\
\text { implementing SEDMS. }\end{array}$ \\
& $\begin{array}{l}\text { Competence of SEDMS managers in the National } \\
\text { Cyber and Crypto Agency. }\end{array}$ \\
\hline
\end{tabular}




\begin{tabular}{llll}
\hline No & Weakness Factor & Code \\
\hline 4 & $\begin{array}{l}\text { Availability of SEDMS manager human } \\
\text { resources. }\end{array}$ & W4 \\
5 & $\begin{array}{l}\text { Planning for the implementation of SEDMS } \\
\text { surroundings the Nation Cyber and Crypto }\end{array}$ & \\
& $\begin{array}{l}\text { Agency. } \\
\text { The function of confidentiality of SEDMS in }\end{array}$ & W6 \\
6 & handling confidential mails. & W7 \\
\hline
\end{tabular}

Source: SWOT Tabulation Results.

Next is the identification of opportunity and threat factors. Just like before, based on the tabulation results, the general preference value for external factors is 3,7. So, if an external factor has a preference value greater than 3.7, then it is said to be an opportunity factor, and if an internal factor has a preference value less than 3.7 , then it is said to be a threat factor.

Table 6. Opportunity Factor

\begin{tabular}{|c|c|c|}
\hline No & Opportunity Factor & Code \\
\hline 1 & $\begin{array}{l}\text { Leader support for the implementation of } \\
\text { SEDMS. }\end{array}$ & $\mathrm{O} 1$ \\
\hline 2 & $\begin{array}{l}\text { The long-term effect of implementing SEDMS on } \\
\text { correspondence business processes. }\end{array}$ & $\mathrm{O} 2$ \\
\hline 3 & $\begin{array}{l}\text { Motivation of users of SEDMS surroundings the } \\
\text { National Cyber and Crypto Agency. }\end{array}$ & $\mathrm{O} 3$ \\
\hline 4 & Budget availability. & $\mathrm{O} 4$ \\
\hline 5 & $\begin{array}{l}\text { Availability of supporting infrastructure for } \\
\text { SEDMS implementation. }\end{array}$ & O5 \\
\hline 6 & $\begin{array}{l}\text { User participation in the series of SEDMS } \\
\text { implementation processes. }\end{array}$ & O6 \\
\hline 7 & $\begin{array}{l}\text { Competence of SEDMS users surroundings the } \\
\text { National Cyber and Crypto Agency. }\end{array}$ & $\mathrm{O} 7$ \\
\hline
\end{tabular}

Table 7. Threat Factor

\begin{tabular}{lll}
\hline No & Threat Factor & Code \\
\hline 1 & $\begin{array}{l}\text { Organizational readiness for } \begin{array}{l}\text { SEDMS } \\
\text { applications. }\end{array} \\
\text { Culture of Electronization in the National Cyber }\end{array}$ & T2 \\
2 & $\begin{array}{l}\text { and Crypto Agency. } \\
\text { Technology integration. }\end{array}$ & T3 \\
3 & $\begin{array}{l}\text { Collaboration on the development of SEDMS } \\
\text { with other parties. }\end{array}$ & T4 \\
5 & SEDMS management organizational structure. & T5 \\
\hline
\end{tabular}




\begin{tabular}{lll}
\hline No & Threat Factor & Code \\
\hline 6 & $\begin{array}{l}\text { Regulations that support the implementation of } \\
\text { SEDMS. }\end{array}$ & T6 \\
\hline
\end{tabular}

Source: SWOT Tabulation Results.

Based on the identification of strengths, weaknesses, opportunities, and threats that have been explained, furthermore, the SWOT analysis is carried out in producing change actions to support the implementation of SEDMS. These change actions are obtained by analyzing two parts so later it will produce four columns, namely SO (Strength-Opportunity), ST (StrengthThreat), WO (Weakness-Opportunity), and WT (Weakness-Threat).

SO actions change to maximize the strengths of the organization in utilizing existing opportunities, ST actions change to use the strengths of the organization in anticipating emerging threats, WO actions change to minimize existing weaknesses in order to be able to use opportunities existing well, and WT actions change reducing the existing weaknesses to be able to avoid the threats that arise. The SWOT analysis table can be seen in Table VIII below.

Table 8. SWOT Matrix

\begin{tabular}{|c|c|c|}
\hline & $\begin{array}{l}\text { Strength } \\
(\mathrm{S} 1, \mathrm{~S} 2, \mathrm{~S} 3, \mathrm{~S} 4, \mathrm{~S} 5, \mathrm{~S} 6)\end{array}$ & $\begin{array}{l}\text { Weakness } \\
\text { (W1,W2,W3,W4,W5,W6, W7) }\end{array}$ \\
\hline $\begin{array}{l}\text { Opportunity } \\
\text { (O1,O2,O3, } \\
\text { O4,O5,O6, } \\
\text { O7) }\end{array}$ & $\begin{array}{l}\text { SO Strategy: } \\
\text { Maximizing the budget to } \\
\text { create document and archive } \\
\text { security governance to } \\
\text { guarantee its integrity, } \\
\text { authenticity, conformity, and } \\
\text { reliability in a comprehensive } \\
\text { and systematic manner. } \\
\text { Increasing the use of } \\
\text { SEDMS to support the } \\
\text { achievement of the vision and } \\
\text { mission of the organization } \\
\text { accompanied by leaders support } \\
\text { in the long term. } \\
\text { Maximizing the existing } \\
\text { budget to develop applications } \\
\text { so that they can improve their } \\
\text { performance and security. } \\
\text { Intensify socialization } \\
\text { about SEDMS and involve users } \\
\text { in the series of SEDMS } \\
\text { implementation processes. } \\
\text { Utilizing the } \\
\text { implementation of SEDMS to } \\
\text { support employee performance }\end{array}$ & $\begin{array}{l}\text { WO Strategy: } \\
\text { Conduct an assessment of } \\
\text { cryptographic algorithms that are suitable to } \\
\text { guarantee the confidentiality of the mails in } \\
\text { the implementation of SEDMS. } \\
\text { Strengthen employee commitment } \\
\text { through leaders commands as a form of } \\
\text { support for the implementation of SEDMS. } \\
\text { Improve manager competence through } \\
\text { discussion and training forums as a form of } \\
\text { user participation. } \\
\text { Overcoming the lack of human } \\
\text { resources managers by facilitating } \\
\text { competent users to become managers. } \\
\text { Make an implementation plan by the } \\
\text { available budget and supporting } \\
\text { infrastructure. } \\
\text { Conduct internal SEDMS development } \\
\text { by utilizing competent user participation } \\
\text { supported by available budget. }\end{array}$ \\
\hline
\end{tabular}




\begin{tabular}{|c|c|c|}
\hline & $\begin{array}{l}\text { Strength } \\
(\mathrm{S} 1, \mathrm{~S} 2, \mathrm{~S} 3, \mathrm{~S} 4, \mathrm{~S} 5, \mathrm{~S} 6)\end{array}$ & $\begin{array}{l}\text { Weakness } \\
\text { (W1,W2,W3,W4,W5,W6, W7) }\end{array}$ \\
\hline $\begin{array}{l}\text { Threat (T1, } \\
\text { T2, T3, T4, } \\
\text { T5, T6). }\end{array}$ & $\begin{array}{l}\text { supported by the motivation and } \\
\text { competence of users of SEDMS. } \\
\text { Maximizing infrastructure } \\
\text { that supports SEDMS } \\
\text { implementation so that the } \\
\text { effectiveness and efficiency of } \\
\text { correspondence can be } \\
\text { increased. } \\
\text { ST Strategy: } \\
\text { Adapt the culture of } \\
\text { electronization and increase } \\
\text { information security awareness. } \\
\text { Increase organizational } \\
\text { readiness with implementation } \\
\text { and education gradually. } \\
\text { Conducting habituation the } \\
\text { use of electronic systems. } \\
\text { Integrate SEDMS and } \\
\text { other systems to achieve } \\
\text { implementation objectives. } \\
\text { Conducting test and assess } \\
\text { the products of other parties } \\
\text { (SEDMS). } \\
\text { Creating SEDMS manager } \\
\text { structure in the organization. } \\
\text { Make regulations that } \\
\text { support the effectiveness and } \\
\text { efficiency of correspondence by } \\
\text { utilizing SEDMS. }\end{array}$ & $\begin{array}{l}\text { WT Strategy: } \\
\text { Improve the features and appearance of } \\
\text { SEDMS as needed to increase comfort so } \\
\text { that users are interested and accustomed to } \\
\text { using it. } \\
\text { Make regulations to strengthen } \\
\text { employee commitment in the process of } \\
\text { implementing SEDMS. } \\
\text { Improve the competence of SEDMS } \\
\text { managers to reduce the involvement of } \\
\text { external parties. } \\
\text { Increase the quantity of SEDMS } \\
\text { managers. } \\
\text { Make plans to increase organizational } \\
\text { readiness. } \\
\text { Integrating correspondence systems } \\
\text { through SEDMS and controlling the } \\
\text { application. }\end{array}$ \\
\hline
\end{tabular}

Mapping the Alteration Management Strategies. After formulating the change actions using SWOT analysis, then mapping the change actions is carried out using the Lewin's ThreeStep Model. This subsection still included in stage D of the thinking system research plot. Mapping the change management strategy is divided into three stages according to Lewin's Three-Step Model. As for the stages are unfreeze stage, movement stage, and freeze stage. The following is a table mapping the action changes. The use of Lewin's Three-Step Model is because this model is a good model used to create information technology implementation strategies [4]. 
Table 9. Mapping the Alteration Management Strategies

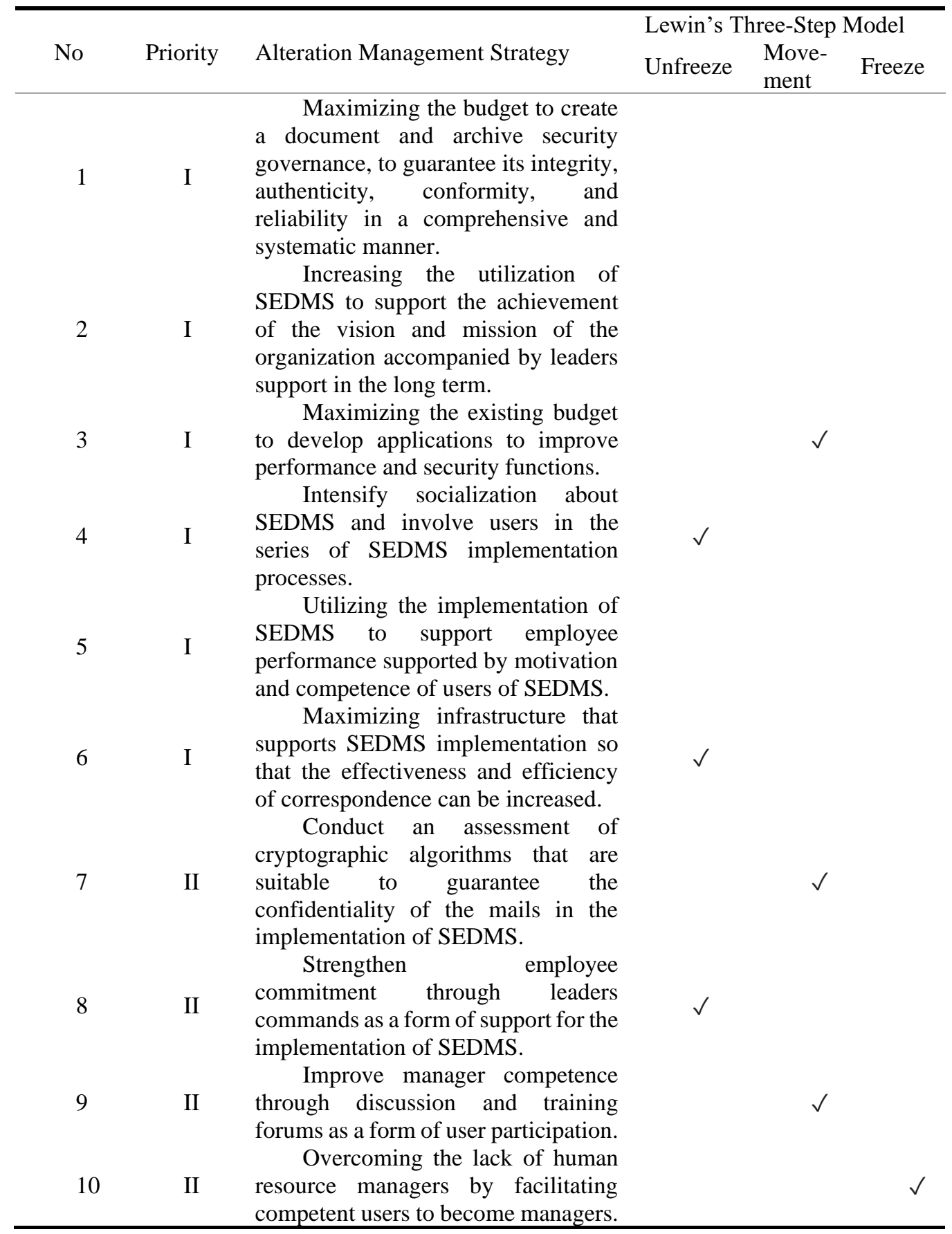




\begin{tabular}{|c|c|c|c|c|c|}
\hline \multirow[b]{2}{*}{ No } & \multirow[b]{2}{*}{ Priority } & \multirow[b]{2}{*}{ Alteration Management Strategy } & \multicolumn{3}{|c|}{ Lewin's Three-Step Model } \\
\hline & & & Unfreeze & $\begin{array}{l}\text { Move- } \\
\text { ment }\end{array}$ & Freeze \\
\hline 11 & II & $\begin{array}{l}\text { Make an implementation plan by } \\
\text { the available budget and supporting } \\
\text { infrastructure. }\end{array}$ & $\checkmark$ & & \\
\hline 12 & II & $\begin{array}{l}\text { Conduct internal SEDMS } \\
\text { development by utilizing competent } \\
\text { user participation supported by } \\
\text { available budget. }\end{array}$ & & & $\checkmark$ \\
\hline 13 & III & $\begin{array}{l}\text { Habituate the culture of } \\
\text { electronization and increase } \\
\text { information security awareness. } \\
\text { Increase organizational }\end{array}$ & & $\checkmark$ & \\
\hline 14 & III & $\begin{array}{l}\text { readiness with implementation and } \\
\text { education gradually. }\end{array}$ & & $\checkmark$ & \\
\hline 15 & III & $\begin{array}{l}\text { Conducting habituation the } \\
\text { utilization of electronic systems. } \\
\text { Integrate SEDMS and other }\end{array}$ & & $\checkmark$ & \\
\hline 16 & III & $\begin{array}{l}\text { systems to achieve implementation } \\
\text { objectives. }\end{array}$ & & & $\checkmark$ \\
\hline 17 & III & $\begin{array}{l}\text { Conducting test and assess the } \\
\text { products of other parties (SEDMS). }\end{array}$ & & $\checkmark$ & \\
\hline 18 & III & $\begin{array}{l}\text { Creating SEDMS manager } \\
\text { structure in the organization. }\end{array}$ & & & $\checkmark$ \\
\hline 19 & III & $\begin{array}{l}\text { Make regulations that support } \\
\text { the effectiveness and efficiency of } \\
\text { correspondence by utilizing SEDMS. }\end{array}$ & & & $\checkmark$ \\
\hline 20 & IV & $\begin{array}{l}\text { Improving the features and } \\
\text { appearance of SEDMS as needed to } \\
\text { increase comfort so that users are } \\
\text { interested and accustomed to using it. } \\
\text { Make regulations to strengthen }\end{array}$ & & $\checkmark$ & \\
\hline 21 & IV & $\begin{array}{l}\text { employee commitment in the process } \\
\text { of implementing SEDMS. }\end{array}$ & & & $\checkmark$ \\
\hline 22 & IV & $\begin{array}{l}\text { Improve the competence of } \\
\text { SEDMS managers to reduce the } \\
\text { involvement of external parties. }\end{array}$ & & $\checkmark$ & \\
\hline 23 & IV & $\begin{array}{l}\text { Increase the quantity of SEDMS } \\
\text { managers. }\end{array}$ & & $\checkmark$ & \\
\hline 24 & IV & $\begin{array}{l}\text { Make plans with the aim of } \\
\text { increasing organizational readiness. } \\
\text { Integrating correspondence }\end{array}$ & $\checkmark$ & & \\
\hline 25 & IV & $\begin{array}{l}\text { systems through SEDMS and } \\
\text { controlling the application. }\end{array}$ & & & $\checkmark$ \\
\hline
\end{tabular}


Based on the above table, we can see the mapping of these change actions into three stages in Lewin's Three-Step Model. The following is a grouping based on these three stages.

Unfreeze Stages. At this stage conducted the activities that help employees to realize the need for the implementation of SEDMS as well as changes to achieve the success of SEDMS and achieve organizational goals, the following is the actions for changes made at this unfreeze stage.

Table 10. The Change Actions of the Unfreeze Stage

\begin{tabular}{lll}
\hline No & Strategy & Priority \\
\hline 1 & $\begin{array}{l}\text { Intensify socialization about SEDMS and involve users in the } \\
\text { series of SEDMS implementation processes. }\end{array}$ & \\
& $\begin{array}{l}\text { Maximizing infrastructure that supports SEDMS } \\
\text { implementation so that the effectiveness and efficiency of I } \\
\text { correspondence can be increased. }\end{array}$ & $\begin{array}{l}\text { Strengthen employee commitment through leadership } \\
\text { commands as a form of support for the implementation of II }\end{array}$ \\
& $\begin{array}{l}\text { SEDMS. } \\
\text { Make an implementation plan by the available budget and }\end{array}$ & II \\
& $\begin{array}{l}\text { supporting infrastructure. } \\
\text { Make plans with the aim of increasing organizational readiness. II }\end{array}$ \\
\hline
\end{tabular}

Movement Stages.

At this stage, changes have been made in stages to achieve new conditions towards the expected conditions. The following are the actions of changes made at this stage of the movement.

Table 11. The Change Actions of the Movement Stage

\begin{tabular}{lll}
\hline No & Strategy & Priority \\
\hline 1 & $\begin{array}{l}\text { Maximizing the existing budget to develop applications so as } \\
\text { to improve performance and security functions. }\end{array}$ & I \\
& $\begin{array}{l}\text { Conduct an assessment of cryptographic algorithms that are } \\
\text { suitable to guarantee the confidentiality of the mails in the } \\
\text { implementation of SEDMS. }\end{array}$ & II \\
& $\begin{array}{l}\text { Improve manager competence through discussion and training } \\
\text { forums as a form of user participation. }\end{array}$ & II \\
3 & $\begin{array}{l}\text { Habituate the culture of electronization and increase } \\
\text { information security awareness. }\end{array}$ & III \\
& $\begin{array}{l}\text { Increase organizational readiness with implementation and } \\
\text { education gradually. }\end{array}$ & III \\
5 & $\begin{array}{l}\text { Conducting habituation the utilization of electronic systems. } \\
\text { Conducting test and assess the products of other parties } \\
\text { (SEDMS). }\end{array}$ & III \\
\hline
\end{tabular}




\begin{tabular}{lll}
\hline No & Strategy & Priority \\
\hline 8 & $\begin{array}{l}\text { Improving the features and appearance of SEDMS as needed } \\
\text { to increase comfort so that users are interested and }\end{array}$ & IV \\
& $\begin{array}{l}\text { accustomed to using it. } \\
\text { Improve the competence of SEDMS managers to reduce the }\end{array}$ & IV \\
9 & $\begin{array}{l}\text { involvement of external parties. } \\
\text { Increase the quantity of SEDMS managers. }\end{array}$ & IV \\
\hline
\end{tabular}

Freeze Stages. At this stage, the changes that have made are permanent and strengthened, so the old ways entirely abandoned.

Table 12. The Change Actions of the Freeze Stage

\begin{tabular}{|c|c|c|}
\hline No & Strategy & Priority \\
\hline 1 & $\begin{array}{l}\text { Maximizing the budget to create a document and archive } \\
\text { security governance, to guarantee its integrity, authenticity, } \\
\text { conformity, and reliability in a comprehensive and systematic } \\
\text { manner. }\end{array}$ & I \\
\hline 2 & $\begin{array}{l}\text { Increasing the utilization of SEDMS to support the } \\
\text { achievement of the vision and mission of the organization } \\
\text { accompanied by leaders support in the long term. }\end{array}$ & I \\
\hline 3 & $\begin{array}{l}\text { Utilizing the implementation of SEDMS to support employee } \\
\text { performance supported by motivation and competence of } \\
\text { users of SEDMS. }\end{array}$ & I \\
\hline 4 & $\begin{array}{l}\text { Overcoming the lack of human resource managers by } \\
\text { facilitating competent users to become managers. }\end{array}$ & II \\
\hline 5 & $\begin{array}{l}\text { Conduct internal SEDMS development by utilizing competent } \\
\text { user participation supported by available budget. }\end{array}$ & II \\
\hline 6 & $\begin{array}{l}\text { Integrate SEDMS and other systems to achieve } \\
\text { implementation objectives. }\end{array}$ & III \\
\hline 7 & Creating SEDMS manager structure in the organization. & III \\
\hline 8 & $\begin{array}{l}\text { Make regulations that support the effectiveness and efficiency } \\
\text { of correspondence by utilizing SEDMS. }\end{array}$ & III \\
\hline 9 & $\begin{array}{l}\text { Make regulations to strengthen employee commitment in the } \\
\text { process of implementing SEDMS. }\end{array}$ & IV \\
\hline 10 & $\begin{array}{l}\text { Integrating correspondence systems through SEDMS and } \\
\text { controlling the application. }\end{array}$ & IV \\
\hline
\end{tabular}

\section{Conclusion.}

Based on the research which has done, can be concluding that there is several things answer the research questions that have formulated previously. The conclusion of this research is: 
Based on the analysis that has been carried out, the condition of the National Cyber and Crypto Agency when related to the implementation of SEDMS namely in terms of technological readiness, the National Cyber and Crypto Agency has fulfilled the infrastructure needs for the development of SEDMS since 2009. In terms of top management support, the National Cyber and Crypto Agency leaders also support the implementation of SEDMS. Furthermore, in terms of training and involvement, the socialization related to SEDMS has been conducted to staff and several structural officials. In terms of resource availability, the allocation of funds has also provided for development to the implementation of SEDMS. Then in terms of system-related factors, namely basically SEDMS is functioning but not optimal yet. Related to the work environment and culture, namely employees of the National Cyber and Crypto Agency still need to make adjustments to changes from a manual to an electronic correspondence system.

Based on the results of the analysis conducted, internal and external factors related to the process of developing and implementing SEDMS has obtained from the results of data analysis conducted. As for the internal and external factors is infrastructure availability, technology integration, leaders support, organization structure, utilization of SEDMS, user participation, information related to SEDMS, user competence, managers competence, cooperation of development, budget availability, human resources availability, internal development, effectiveness and efficiency of correspondence, SEDMS security function, long-term influence, comfort of use, implementation planning, and electronization culture.

As for, an alteration management strategy which is expected to be effective in supporting the implementation of SEDMS in the National Cyber and Crypto Agency is mapped using Lewin's Three-Step Change Model. The strategy described into actions of change which divided into actions in stages, namely unfreeze, change, and freeze. The actions in the unfreeze process consist of preparation for the implementation of SEDMS, the movement process consists of changes made, and the freeze process consists of standardizing and establishing a new system.

\section{Recommendation.}

Based on research that has done, we suggested the following things:

Further research is needed on the technical suitability of the system. Risk analysis is required if all systems have been changed to electronic. In changing the system from manual to electronic, it expected that the National Cyber and Crypto Agency would do it gradually.

\section{References}

[1] M. Christine, Rancangan Kebijakan dan Prosedur Secure Electronic Document Management System (SEDMS): Studi Kasus BSSN, Jakarta: Universitas Indonesia, 2014.

[2] P. B. Lientz and P. K. Rea, Breaktrough IT Change Management: How To Get Enduring Change Results, 1st penyunt., New York: Elsver Butterworth Heinemann, 2004.

[3] M. N. Nasution, Manajemen Perubahan, Jakarta: Ghalia Indonesia, 2010.

[4] G. T. Cummings and G. Worley, Organizational Development and Change: International Student Edition, 9th penyunt., Southwestern: South-Western Cengage Learning, 2008.

[5] G. S. Haines, Enterprise-Wide Change, Superior Results through System Thinking, San Francisco: John Wiley \& Sons, Inc, 2005.

[6] Sugiyono, Metodologi Penelitian Kuantitatif Kualitatif dan R\&D, Bandung: Alfabeta, 2011.

[7] M. C. Olszak and E. Ziemba, "Critical Success Factors for Implementing Business Intelligence Systems in Small and Medium Enterprises on the Example of Upper Silesia”, Interdisciplinary Journal of Information, Knowledge and Management, Vol. 7, 2012.

[8] B. M. Sukoco, Manajemen Administrasi Perkantoran Modern, Jakarta: Erlangga, 2005. 